\begin{tabular}{|c|c|c|}
\hline ENGINEERING CHANGE NOTICE & Pege 1 af $Q$ & $\begin{array}{l}\text { 1. ECN } 6 j=7 ? \\
\text { Proj. }\end{array}$ \\
\hline
\end{tabular}

\begin{tabular}{|c|c|c|c|c|c|c|}
\hline \multirow{3}{*}{$\begin{array}{l}\text { 2. ECN Category } \\
\text { (mark one) } \\
\text { Supplementel } \\
\text { Oirect Revision } \\
\text { Change ECN } \\
\text { Temporary } \\
\text { Standby } \\
\text { Supersedure } \\
\text { Cancel/Void }\end{array}$} & \multirow{3}{*}{$\begin{array}{r}{[]} \\
{[\mathrm{X}]} \\
{[]} \\
{[]} \\
{[]} \\
{[]} \\
{[]}\end{array}$} & \multicolumn{2}{|c|}{$\begin{array}{l}\text { 3. Originator's Name, Organization, MSIN, } \\
\text { and Telephone No. } \\
\text { Clarence Homi Evaluation and } \\
\text { Planning, R2-12, } 373-1097\end{array}$} & \multicolumn{2}{|c|}{$\begin{array}{l}\text { 3a. USQ Required? } \\
{[] \text { Yes }[X] \text { No }}\end{array}$} & $\begin{array}{l}\text { 4. Date } \\
05 / 09 / 96\end{array}$ \\
\hline & & \multicolumn{2}{|c|}{$\begin{array}{l}\text { 5. Project Title/No./Work Order No. } \\
\text { Tank 241-U-103 }\end{array}$} & \multicolumn{2}{|c|}{$\begin{array}{l}\text { 6. Bldg./Sys./Fac. No. } \\
241-U-103\end{array}$} & $\begin{array}{c}\text { 7. Approval Designator } \\
N / A\end{array}$ \\
\hline & & \multicolumn{2}{|c|}{$\begin{array}{l}\text { 8. Document Numbers Changed by this ECH } \\
\text { (includes sheet no. and rev.) } \\
\text { WHC-SD-WM-TP-288, Rev. I-A }\end{array}$} & \multicolumn{2}{|c|}{$\begin{array}{l}\text { 9. Related ECN No(s). } \\
\text { ECNs: } 625723 \text {. } \\
627005\end{array}$} & $\begin{array}{l}\text { 10. Related PO No. } \\
\qquad N / A\end{array}$ \\
\hline \multirow{2}{*}{\multicolumn{2}{|c|}{$\begin{array}{l}\text { 11a. Modification Work } \\
\text { [] Yes (filt out B(k. } \\
\text { 11b) } \\
{[X] \text { No (NA Blks. 11b, }} \\
11 c, 11 d \text { ) }\end{array}$}} & \multirow[t]{2}{*}{$\begin{array}{l}\text { 11b. Work Packoge } \\
\text { No. } \\
\text { N/A }\end{array}$} & \multirow{2}{*}{\multicolumn{2}{|c|}{$\begin{array}{l}\text { 11c. Modification Work Complete } \\
\text { N/A }\end{array}$}} & \multicolumn{2}{|c|}{$\begin{array}{l}\text { 11d. Restored to Original Condi- } \\
\text { tion (Temp. or Standby ECN only) } \\
\text { N/A }\end{array}$} \\
\hline & & & & & Cog. En & neer Signature \& Date \\
\hline
\end{tabular}

12. Description of Change

Complete revision.

13a. Justification (mark one)

\begin{tabular}{llllllll} 
Criteria Change & {$[X]$} & Design Improvement & {[]} & Enviromental & {[]} & Facility Deactivation \\
As-Found & {[]} & Facilitate Const & {[]} & Const. Error/Omission & [] & Design Error/Omission \\
\hline
\end{tabular}

13b. Justification Details

Changed to comply with new template and DOE-RL recommended modifications.

14. Distribution (include name, MSIN, and no. of copies)

See attached distribution. 


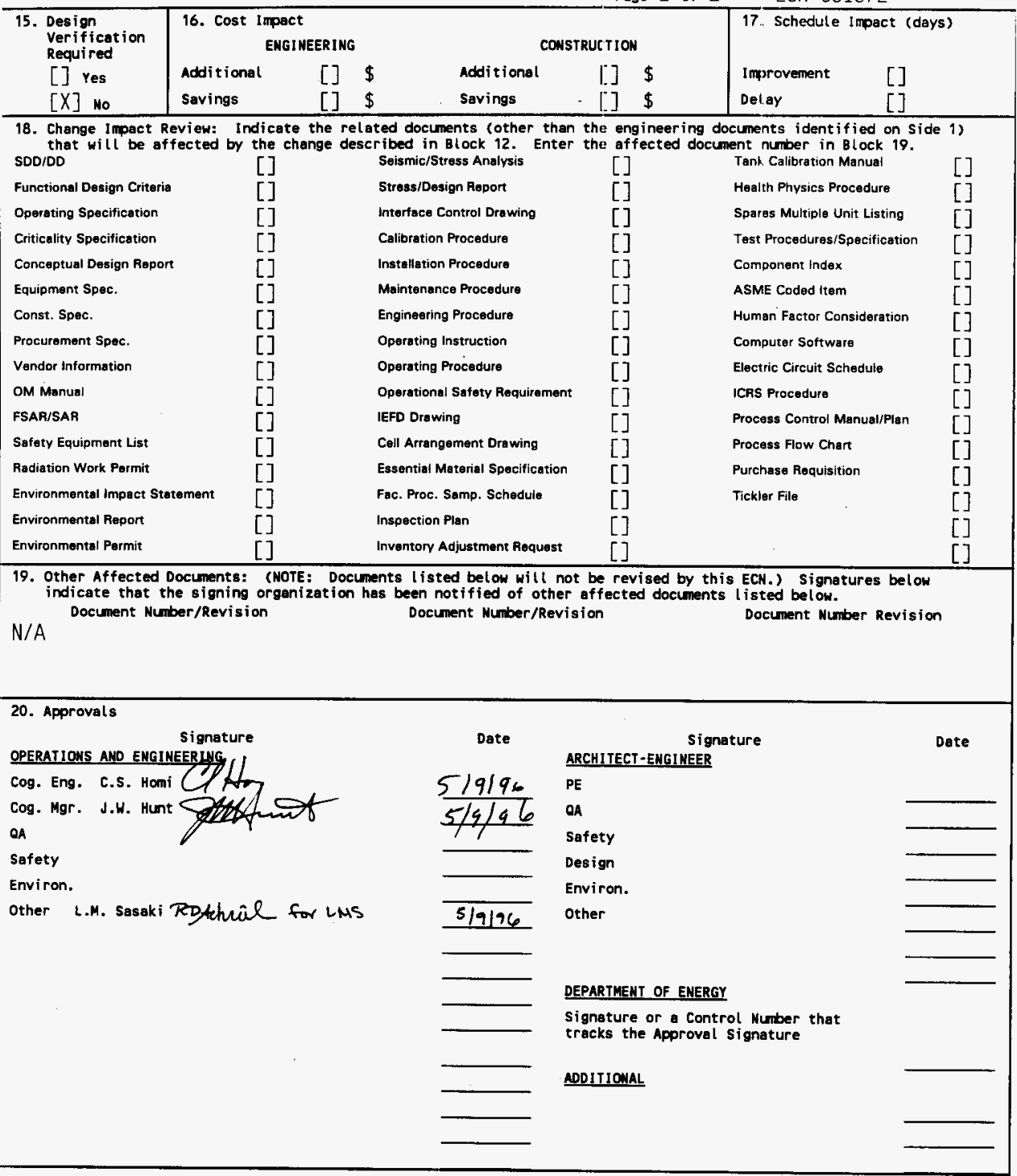




\section{Tank 241-U-103 Tank Characterization Plan}

\section{S. Homi}

Westinghouse Hanford Company. Richland, WA 99352

U.S. Department of Energy Contract DE-AC06-87RL10930

$\begin{array}{lll}\text { EDT/ECN: } & \text { ECN-631572 } & \text { UC: } 2070 \\ \text { Org COde: } & 79200 & \text { Charge Code: N4G6A } \\ \text { B\&R Code: } & \text { EW } 3120074 & \text { Tota1 Pages: } 10\end{array}$

Key Words: Characterization. General Safety Issues, Specific Safety Issues. Information Requirements. Schedule

Abstract: This document is a plan that identifies the information needed to address relevant issues concerning short-term and long-term storage and long-term management of single-shell tank 241-U-103.

TRADEMARK DISCLAIMER. Reference herein to any specific commercial product, process, or service by trade neme, trademerk, manufacturer, or otherwise, does not necessarily constitute or imply its endorsement, recommendation, or favoring by the United States Government or any agency thereof or its contractors or subcontractors.

Printed in the United States of America. To obtain copies of this document, contact: HHC/BCS Document Control Services, P.O. Box 1970, Mailstop H6-08, Richland UA 99352, Phone (509) 372-2420; Fax (509) 376-4989.
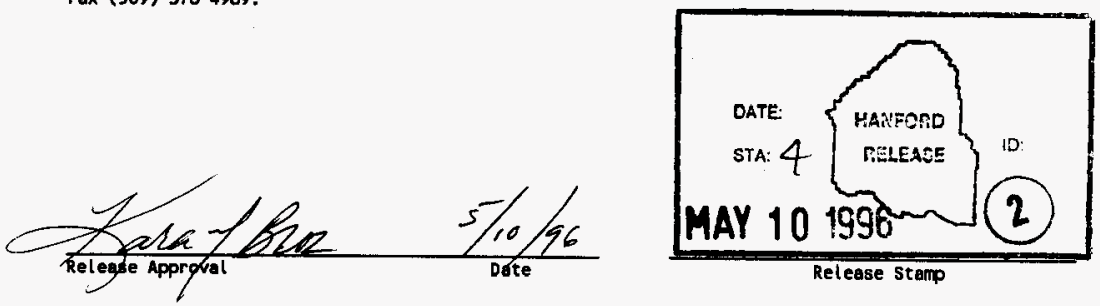

\section{Approved for Public Release}


RECORD OF REVISION

(2) Title

TANK 241-U-103 TANK CHARACTERIZATION PLAN

CHANCE CONTROL RECCRO

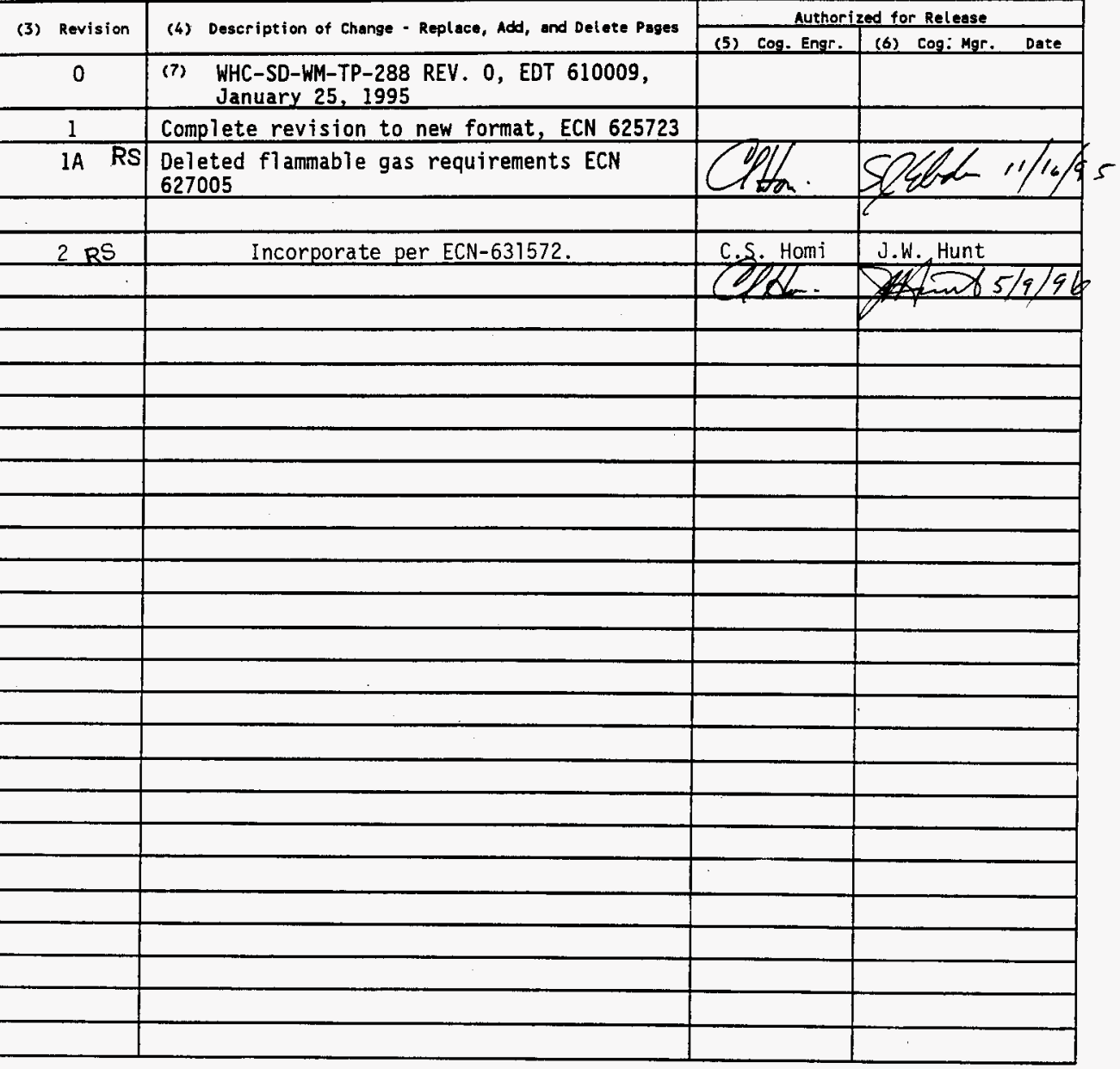


WHC-SD-WM-TP-288

Revision 2

UC-2070

\section{Tank 241-U-103 Tank Characterization Plan}

L. M. Sasaki

Westinghouse Hanford Company

Date Published

May 1996

Prepared for the U.S. Department of Energy Office of Environmental Restoration and Waste Management

\section{Westinghouse p.o. Box 1970 Hanford Company Richand, Wastingeon}

Management and Operations Contractor for the

U.S. Department of Energy under Contract DE-AC06-87RL10930 
WHC-SD-WM-TP-288, REV 2

TABLE OF CONTENTS

1.0 INTRODUCTION . . . . . . . . . . . . . . . . . . . I

2.0 PROGRAN ELEMENTS REQUIRING INFORMATION FOR TANK 241-U-103 . . . . 2

2.1 GENERAL SAFETY ISSUES . . . . . . . . . . . . . . . . . 2

2.2 SPECIFIC SAFETY ISSUES . . . . . . . . . . . . . . . . 2

2.2.1 Ferrocyanide ................... 2

2.2.2 Organic................... 2

2.2.3 High Heat ..................... . 2

2.2.4 Flammable Gas.................. 2

2.2 .5 Vapor ..................... 2

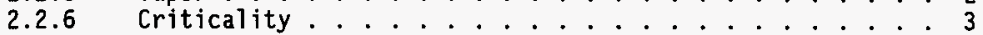

2.3 CONTINUING OPERATIONS ...................... 3

2.3.1 Compatibility/Stabilization ............ 3

2.3.2 Evaporator ................. 3

2.4 DOUBLE-SHELL TANK WASTE ANALYSIS PLAN . . . . . . . . . . . . . 3

2.5 DISPOSAL . . . . . . . . . . . . . . . . . . . . 3

2.5.1 Retrieval .................... 3

2.5.2 Pretreatment/vitrification .............. 4

2.6 HISTORICAL MODEL EVALUATION ................... . . 4

3.0 HOW INFORMATION WILL BE OBTAINED . . . . . . . . . . . . . . . . . 4

4.0 PRIORITY OF INFORMATION REQUIRENENTS . . . . . . . . . . . . . . 4

5.0 WHEN INFORMATION WILL BE AVAILABLE ................ 5

6.0 REFERENCES . . . . . . . . . . . . . . . . . . . 5

\section{LIST OF TABLES}

4-1 Integrated DQ0 Requirements and Priorities . . . . . . . . . . 5 


\section{WHC-SD-HM-TP-288, REV 2}

\subsection{INTRODUCTION}

This Tank Characterization Plan (TCP) identifies the information needed to address relevant issues concerning short-term and long-term safe storage and long-term management of single-shell tank 241-U-103 (U-103). It should be understood that the various needs and issues surrounding tank U-103 are evolving as new information about the tank is uncovered. As a result of this progression, this TCP addresses only the issues that, to this date, have been identified. It is expected that deviations from this plan may occur as additional issues or needs arise which impact the management of tank U-103. As necessary, this TCP will be revised to reflect those changes or deviations. This plan reflects the best information available as of May 1996.

Tank U-103 was constructed between 1943 and 1944 and was put into service in February 1947. Tank U-103 received metal waste from the first quarter of 1947 until the fourth quarter of 1956 . During 1955, waste was removed for the uranium recovery process and in the fourth quarter of 1956, the heel was sluiced. The tank received reduction oxidation (REDOX) waste from the first quarter of 1957 until the second quarter of 1975 . Tank U-103 also occasionally received waste water between 1952 and 1976 . From the third quarter of 1975 to the fourth quarter of 1977, the tank received transfers of evaporator feed and other wastes from various tanks. In the fourth quarter of 1977, the tank received NIT, a $\mathrm{HNO}_{3} / \mathrm{KMnO}_{4}$ solution used for partial neutralization of evaporator feed (Agnew et al. 1996). Currently, the waste is classified as non-complexed waste.

The tank is classified as sound and was labelled inactive in 1978. Tank U-103 is passively ventilated and has been partially isolated. The tank is awaiting interim stabilization (Brevick et al. 1995).

Tank U-103 currently contains a total volume of $1,771 \mathrm{~kL}$ (468 kgal) of waste, which is equivalent to $422 \mathrm{~cm}$ (166 in) of waste as measured from the baseline of the tank (Hanlon 1996).

This tank is on the Flammable Gas and Organic Watch Lists.

Near-term sampling and analysis activities are focused on either verifying or changing the Watch List tank status and identifying any new safety issues. Should any other safety issues be identified, additional analysis will occur consistent with the identified issue.

In addition to the resolution of the safety issues, it is intended that all tank waste will be subject to pretreatment and retrieval to prepare for final storage or disposal. Presently, these long-range plans have yet to be fully identified and are, therefore, not included in this document. 
WHC-SD-WM-TP-288, REV 2

\subsection{PROGRAM ELEMENTS REQUIRING INFORMATION FOR TANK 241-U-103}

This section identifies the various program elements, and identifies which of these programs require characterization data from tank U-103.

\subsection{GENERAL SAFETY ISSUES}

The Tank Safety Screening Data Quality Objective (Dukelow et a1. 1995) describes the sampling and analytical requirements that are used to screen waste tanks for unidentified safety issues. Analytical requirements for the safety screening of a tank are energetics, total alpha activity, moisture content, density and flammable gas concentration.

\subsection{SPECIFIC SAFETY ISSUES}

\subsubsection{Ferrocyanide}

This tank is not on the Ferrocyanide Watch List; therefore, no information needs are currently identified for this program element.

\subsubsection{Organic}

This tank is on the Organic Watch List. Sampling and analys is requirements must be performed per the Data Quality Objective to Support Resolution of the Organic Complexant Safety Issue (Turner et al. 1995). The analyses employed will determine the total organic carbon (TOC), energetics, presence of a free organic liquid phase, and moisture content.

\subsubsection{High Heat}

This tank is not on the High Heat Watch List; therefore, no information needs are currently identified for this program element.

\subsubsection{Flammable Gas}

This tank is on the Flammable Gas Watch List. The applicable data quality objective (DQ0) for this safety issue is Flammable Gas Safety Program: Data Requirements for Core Sample Analysis Developed through the Data Quality Objectives Process (McDuffie 1995). However, the DQO states that core sampling of the single-shel1 tanks that are part of the Flammable Gas Watch List is not planned at this time.

\subsubsection{Vapor}

A11 177 underground tanks must be vapor sampled for organic solvent screening as per Recommendation 93-5 Implementation Plan (DOE-RL 1996). Some tanks may require additional vapor sampling due to other program needs. These tanks may be classified into four categories: (1) those tanks which are to be rotary mode core sampled (as a consequence of the rotary mode core sampling system exhauster 


\section{WHC-SD-WM-TP-288, REV 2}

permit requirements); (2) tanks on the Organic or Ferrocyanide Watch Lists; (3) tanks in C farm; and (4) tank 241-BX-104 due to vapor exposure. Information needs must satisfy Data Quality objectives for Tank Hazardous Vapor Safety Screening (Osborne and Buckley 1995) and for rotary mode core only, Rotary Core Vapor Sampling Data Quality Objective (Price 1994) and Data Quality Objective for Regulatory Requirements for Hazardous and Radioactive Air Emissions Sampling and Analysis (Mulkey and Markillie 1995) as amended by Status of the Current Understanding of the Toxic Air Pollutants (TAPS) and Hanford Tank Farm Vapor Space Characterization; Recommended Path Forward and Justification for Cont inued RMCS Exhauster Operations (Laws 1996). (1994).

Tank U-103 was vapor sampled in February 1995 in support of Osborne et al.

\subsubsection{Criticality}

No information separate from that for the general safety issue of tank U-103 are currently identified for this program element. However, if the general safety screening of tank $U-103$ identifies a potential criticality concern, analyses for fissile materials and neutron sorbers and poisons will be performed as identified in the safety screening DQO.

\subsection{CONTINUING OPERATIONS}

\subsubsection{Compatibility/Stabilization}

Tank U-103 waste was sampled to determine compatibility. Sampling and analysis requirements were performed per the Data Quality Objectives for the Waste Compatibility Program (Carothers 1994). The analyses employed were transuranics such as ${ }^{239} \mathrm{Pu}$ and ${ }^{241} \mathrm{Am}$, total organic carbon (TOC), and heat generation as determined by the amount of ${ }^{90} \mathrm{Sr}$ and ${ }^{137} \mathrm{Cs}$.

\subsubsection{Evaporator}

This section does not apply to tank U-103.

\subsection{DOUBLE-SHELL TANK WASTE ANALYSIS PLAN}

This section does not apply because tank $U-103$ is a single-shell tank.

\subsection{DISPOSAL}

\subsubsection{Retrieval}

Current retrieval needs (Bloom and Nguyen 1995) do not call for test samples to be taken from tank U-103. 


\section{WHC-SD-WM-TP-288, REV 2}

\subsubsection{Pretreatment/Vitrification}

Tank U-103 has not been identified as a bounding tank for pretreatment/ disposal process development strategy (Kupfer et a1. 1995). All tanks were prioritized using the pretreatment strategy in the Tank Waste Characterization Basis (Brown et al. 1995) document and a portion of archive sample material could be used for pretreatment testing if available. The strategy does not require any specific analyses to be done on the samples.

\subsection{HISTORICAL MODEL EVALUATION}

This tank is identified as an acceptable alternative for the spatially complex tank 241-S-107 (S-107) in Historical Model Evaluation Data Requirements (Simpson and McCain 1995). The applicability of these analyses will be determined based on tank S-107's sampling and analysis and will be documented in the tank specific sample and analysis plan.

\subsection{HOW INFORMATION WILL BE OBTAINED}

The number of samples required to characterize a tank is a function of waste heterogeneity and the desired confidence to make a correct decision. As directed by the safety screening DQO, if inadequate information exists to determine an appropriate number of samples, two vertical profiles will be obtained. These vertical profiles may be obtained using core, auger (for shallow tanks), or grab samples. If analysis of these profiles reveals that additional profiles are necessary to meet data needs, more sample profiles will be requested.

\subsection{PRIORITY OF INFORMATION REQUIREMENTS}

Vapor sampling was completed in February 1995. Grab sampling was completed in May 1995. Push mode core sampling is scheduled to begin in July 1996 (Stanton 1996). Refer to Table 4-1 for the current DQO requirements and $\mathrm{planned}$ sampling and analytical requirements. 
WHC-SD-WM-TP-288, REV 2

Table 4-1: Integrated DQO Requirements and Priorities

\begin{tabular}{|l|l|l|l|}
\hline $\begin{array}{c}\text { Sampling } \\
\text { Event }\end{array}$ & Applicable Issues & Sampling Requirements & Analytical Requirements \\
\hline $\begin{array}{l}\text { Vapor } \\
\text { Samp1ing }\end{array}$ & $\begin{array}{l}\text {-Organic Solvent Layer } \\
93-5 \text { Vapor Issue } \\
\text {-Hazardous Vapor DQO }\end{array}$ & $\begin{array}{l}\text { Steel canisters, } \\
\text { Triple Sorbent Traps, } \\
\text { Sorbent Trap Systems }\end{array}$ & $\begin{array}{l}\text { Flammable Gas } \\
\text { Organic Vapors } \\
\text { Permanent Gases }\end{array}$ \\
\hline $\begin{array}{l}\text { Grab } \\
\text { Samp1ing }\end{array}$ & -Compatibility DQO & 3 grab samples & $\begin{array}{l}\text { Energetics, Moisture, } \\
\text { Anions, Cations, } \\
\text { Radionuclides, TOC, pH, } \\
\text { Specific gravity, Total } \\
\text { inorganic carbon, } \\
\text { Separable organics, } \\
\text { Percent solids }\end{array}$ \\
\hline $\begin{array}{l}\text { Push Core } \\
\text { Samp1ing }\end{array}$ & $\begin{array}{l}\text {-Safety Screening DQO } \\
\text {-Organic DQ0 } \\
\text {-Flammable Gas DQO } \\
\text { (see Section 2.2.4) }\end{array}$ & $\begin{array}{l}\text { Core samples from 2 } \\
\text { risers separated } \\
\text { madially to the } \\
\text { maximum extent } \\
\text { possible. } \\
\text { Combust ible gas } \\
\text { measurement. }\end{array}$ & $\begin{array}{l}\text { Flammability, Energetics, } \\
\text { Moisture, Density, Tota] } \\
\text { alpha activity, TOC, } \\
\text { Separable organics }\end{array}$ \\
\hline
\end{tabular}

* Consult each applicable DQO in force at the time for sampling and analytical requirements.

\subsection{WHEN INFORMATION WILL BE AVAILABLE}

According to Stanton (1996) data are expected to be available from the push core sampling event for tank U-103 in November 1996. This time may be a)tered if the sampling schedule changes. Data are available for the February 1995 vapor sampling and the May 1995 grab sampling.

\subsection{REFERENCES}

Agnew, S. F., R. A. Corbin, T. B. Duran, K. A. Jurgensen, T. P. Ortiz, and B. L. Young, 1996, Waste Status and Transaction Record Summary for the Southwest Quadrant of the Hanford 200 Area, WHC-SD-WM-TI-614, Rev. 1, Westinghouse Hanford Company, Richland, Washington.

Bloom, G. R. and Q. H. Nguyen, 1995, Characterization Data Needs for Development, Design and Operation of Retrieval Equipment Developed Through the Data Quality Objective Process, WHC-SD-WM-DQ0-008, Rev. 0, Westinghouse Hanford Company, Richland, Washington. 


\section{WHC-SD-WM-TP-288, REV 2}

Brevick, C. H., L. A. Gaddis, and W. W. Pickett, 1995, Historical Tank Content Estimate for the Southwest Quadrant of the Hanford 200 East Areas, WHC-SD-WM-ER-352, Rev. OA, Westinghouse Hanford Company, Richland, Washington.

Brown, T. M., S. J. Eberlein, and T. J. Kunthara, 1995, Tank Waste Characterization Basis, WHC-SD-WM-TA-164, Rev. 1, Westinghouse Hanford Company, Richland, Washington.

Carothers, K. G, 1994, Data Quality Objectives for the Waste Compatibility Program, WHC-SD-WM-DQO-001, Rev. 0, Westinghouse Hanford Company, Richl and, Washington.

DOE-RL, 1996, Recommendation 93-5 Implementation Plan, DOE/RL-94-0001, Rev. 1, U.S. Department of Energy, Richland, Washington.

Dukelow, G. T., J. W. Hunt, H. Babad, and J. E. Meacham, 1995, Tank Safety Screening Data Quality Objective, WHC-SD-WM-SP-004, Rev. 2, Richland, Washington.

Hanlon, B.M., 1996, Waste Tank Summary for Month Ending January 31, 1996, WHC-EP-0182-94, Westinghouse Hanford Company, Richiand, Washington.

Kupfer, M. J., W. W. Schultz, and J. T. Slankas, 1995, Strategy for Sampling Hanford Site Tank Wastes for Development of Disposa7 Technology, WHC-SD-WM-TA-154, Rev. 1, Westinghouse Hanford Company, Richland, Washington.

Laws, G. L., 1996, Status of the Current Understanding of the Toxic Air Pollutants (TAPS) and Hanford Tank Farm Vapor Space Characterization; Recommended Path Forward and Justification for Continued RMCS Exhauster Operations, (telephone conference memorandum 01830-96-022, to Distribution, March 8), Westinghouse Hanford Company, Richland, Washington.

McDuffie, N. G., 1995, Flammab7e Gas Tank Safety Program: Data Requirements for Core Sample Analysis Developed Through the Data Quality Objectives Process, WHC-SD-WM-DQO-004, Rev. 2, Westinghouse Hanford Company, Richland, Washington.

Mulkey, C. H., and K. D. Markillie, 1995, Data Quality Objective for Regulatory Requirements for Hazardous and Radioactive Air Emissions Sampling and Analysis, WHC-SD-WM-DQ0-021, Rev. 0, Westinghouse Hanford Company, Richland, Washington.

Osborne, J. W., J. L. Huckaby, E. R. Hewitt, C. M. Anderson, D. D. Mahlum, B. A. Pulsipher, and J. Y. Young, 1994, Data Quality Objectives for Generic In-Tank Health and Safety Vapor Issue Resolution, WHC-SD-WM-DQ0-002, Rev. 0, Westinghouse Hanford Company, Richland, Washington. 


\section{WHC-SD-WM-TP-288, REV 2}

Osborne, J. W., and L. L. Buckley, 1995, Data Quality Objectives for Tank Hazardous Vapor Safety Screening, WHC-SD-WM-DQO-002, ReV. 2, Westinghouse Hanford Company, Richland, Washington.

Price, D. N., 1994, Rotary Core Vapor Sampling Data Quality Objective, WHC-SD-WM-SP-003, Rev. O, Westinghouse Hanford Company, Richland, Washington.

Simpson, B. C., and D. J. McCain, 1995, Historical Model Evaluation Data Requirements, WHC-SD-WM-DQO-018, Rev. OA, Westinghouse Hanford Company, Richl and, Washington.

Stanton, G. A., 1996, Base7ine Sampling Schedule, Change 96-02, (internal memo 75610-96-06, to Distribution, Apri1 17), Westinghouse Hanford Company, Richl and, Washington.

Turner, D. A., H. Babad, L. L. Buckley and J. E. Meacham, 1995, Data Quality Objective to Support Resolution of the Organic Complexant Safety Issue, WHC-SD-WM-DQ0-006, Rev. 2, Westinghouse Hanford Company, Richland, Washington. 


\section{DISTRIBUTION SHEET}

\begin{tabular}{|c|c|c|c|c|c|}
\hline \multirow{2}{*}{$\begin{array}{l}\text { To } \\
\text { Distribution }\end{array}$} & \multirow{2}{*}{\multicolumn{3}{|c|}{$\begin{array}{l}\text { From } \\
\text { Evaluation and Planning }\end{array}$}} & \multicolumn{2}{|l|}{ Page 1 of 1} \\
\hline & & & & \multicolumn{2}{|c|}{ Date $\quad 05 / 09 / 96$} \\
\hline \multicolumn{4}{|c|}{ Project Title $/$ Work Order } & \multicolumn{2}{|c|}{ EDT No. N/A } \\
\hline \multicolumn{4}{|c|}{$\begin{array}{l}\text { WHC-SD-WM-TP-288, Rev. 2, "Tank 241-U-103 Tank Characterization } \\
\text { Plan" }\end{array}$} & \multicolumn{2}{|c|}{ ECN No. ECN-631572 } \\
\hline Name & MSIN & $\begin{array}{c}\text { Text } \\
\text { With } \\
\text { All } \\
\text { Attach. }\end{array}$ & Text Only & $\begin{array}{l}\text { Attach. / } \\
\text { Appendix } \\
\text { Only }\end{array}$ & $\begin{array}{l}\text { EDT/ECN } \\
\text { Only }\end{array}$ \\
\hline
\end{tabular}

ONSITE

U. S. Department of Energy -

Richland Field office

W. Liou

S7 $-54 \quad x$

N. W. Willis

S7-54 $\quad x$

Westinghouse Hanford Company

G. D. Forehand

S7-21 $\quad x$

C. S. Homi

L. M. Sasaki

Central Files

T.C.R.C.

R2-12

$\mathrm{R} 2-12$

A3-88

R2-12

$x$
$x$
$x$
$x$
$x$

\section{OFFSITE}

U. S. Department of Enerqy - Headquarters

Office of Environmenta 7 Restoration and

Waste Management EM-563

12800 Middlebrook Road

Germantown. MD 20874

J. A. Poppiti 